\title{
Hematological, clinical and epidemiological aspects of Hepatozoon canis infection by parasitological detection in dogs from the rural area of Sousa, Paraíba, Brazil
}

\author{
Leonardo Vinícius Silva de Oliveira ${ }^{1}\left({ }^{\infty}\right.$ Radabley Rith Almeida de Oliveira ${ }^{1} \odot$ \\ Émerson Timóteo de Alcântara ${ }^{1}\left(\right.$ Felipe Boniedj Ventura Álvares ${ }^{1}\left(\right.$ Thais Ferreira Feitosa ${ }^{1}$ (๑) \\ Arthur Willian de Lima Brasil ${ }^{2}$ ([) Vinícius Longo Ribeiro Vilela ${ }^{1 *}([)$
}

\begin{abstract}
${ }^{1}$ Departamento de Medicina Veterinária, Instituto Federal da Paraíba (IFPB), 58800-970, Sousa, PB, Brasil. E-mail: vinicius.vilela@ifpb.edu.br. ${ }^{*}$ Corresponding author.

${ }^{2}$ Departamento de Morfologia, Universidade Federal da Paraíba (UFPB), João Pessoa, PB, Brasil.

ABSTRACT: Hepatozoonosis is caused by protozoa of the genus Hepatozoon. In dogs, the infection is caused mainly by Hepatozoon canis, and there are a few descriptions of the prevalence of this infection in the Northeast region of Brazil, especially in the semi-arid region. Therefore, we aimed to determine the prevalence of Hepatozoon canis infection in dogs in the rural area of Sousa, Paraiba, Brazil, as well as to determine the possible clinical and epidemiological aspects of this infection. Ninety-eight dogs in the rural zone of the municipality of Sousa that were at least 4 months old were evaluated, regardless of their breed or gender. Clinical examinations were carried out, and samples of systemic and peripheral blood were collected to determine the presence of the parasite in blood smears and carry out hemograms. In addition, epidemiological questionnaires about animal health and food management were completed. The prevalence of $H$. canis infections in dogs was $8.1 \%$ (8/98). There were three main changes in the hematological status: thrombocytopenia, anemia and hyperproteinemia, mainly related to percentage of leukocyte infection $\geq 5 \%$, and also to the presence of clinical signs such as mucopurulent secretion, lymphadenomegaly, dry skin, pale mucous membranes, and lean or cachectic body score.
\end{abstract}

Key words: dogs, hematological changes, hepatozoonosis, Northeast, Brazil.

Aspectos hematológicos, clínicos e epidemiológicos da infecção por Hepatozoon canis por deteç̧ão parasitológica em cães da zona rural de Sousa, Paraíba, Brasil

RESUMO: A hepatozoonose é causada por protozoários do gênero Hepatozoon. Em cães, a infecção ocorre principalmente por Hepatozoon canis, sendo escassas as descrições de prevalências desta infecção na região Nordeste do Brasil, sobretudo no Semiárido. Com isso, o trabalho objetivou determinar a prevalência da infecção por Hepatozoon canis em cães da zona rural do município de Sousa, Paraíba, Brasil, como também determinar possíveis sinais clínicos e aspectos epidemiológicos relacionados à esta infecção. Foram avaliados 98 cães da zona rural do municipio de Sousa, independentemente da raça ou sexo, com idade superior a quatro meses. Foram realizados exames clínicos e colhidas amostras de sangue sistêmico e periférico para a pesquisa do parasito em esfregaços sanguíneos e hemogramas. Além disso, foram preenchidos questionários epidemiológicos acerca do manejo sanitário e alimentar dos animais. A prevalência de cães positivos para H. canis foi de 8,1\% (8/98). Foram observados três principais alterações no quadro hematológico, sendo trombocitopenia, anemia e hiperproteinemia, principalmente relacionadas ao percentual de leucócitos infectados $\geq 5 \%$, e também à presença de sinais clínicos, como secreção mucopurulenta, linfadenomegalia, pelos ressecados, mucosas hipocoradas e escore corporal magro ou caquético.

Palavras-chave: alterações hematológicas, cães, hepatozoonose, Nordeste, Brasil.

\section{INTRODUCTION}

The hepatozoonosis is a debilitating and an immunosuppressive disease with a difficult clinical diagnosis and its infection have been described in amphibians, reptiles, birds and mammals (O’DWYER, 2011).

Although, Hepatozoon americanum has been described to be parasites of wild canids
(SILVEIRA et al., 2016), only Hepatozoon canis has been detected in Brazilian domestic dogs (MUNDIM et al., 2008; ANDRÉ et al., 2010; GONÇALVES et al., 2014; RAMOS et al., 2015; LOPES et al., 2019). In rural environments, Amblyomma ovale and Rhipicephalus (Boophilus) microplus have been reported to be the main vectors of $H$. canis (MIRANDA et al., 2011), which is transmitted to the dog at the time of ingestion of 
the infected tick, and may cause hepatozoonosis (BANETH et al., 2003).

The clinical presentation of hepatozoonosis varies according to the level of parasitemia, the immune status of the animal, and its association with other pathogens (MUNDIM etal. 2008; SPOLIDORIO et al., 2009). Animals may have edema, intermittent fever, weight loss, pale mucous membranes, pain, diarrhea, vomiting, and gait abnormalities (BERNARDINO et al., 2016). However, because these clinical findings are nonspecific, laboratory tests are needed for confirmation (O'DWYER, 2011).

Blood smear examination is the most frequent diagnostic method for $H$. canis infection used to detect gamonts within neutrophils or monocytes, even considered of low sensitivity (BANETH et al., 2003; ROTONDANO et al., 2015). The polymerase chain reaction (PCR) has provided an advanced diagnostic method considered of high sensitivity (LOPES et al., 2019); however, it is not widely used in the routine of veterinary clinics. Hemograms and biochemistry could assist on diagnosis of vector borne diseases, with similar results for several infections (MUNDIM et al., 2008; PAIZ et al., 2016).
The non-specific nature of the clinical signs in infected dogs, associated with the low sensitivity and specificity of the blood smear technique is a hindrance to the good understanding of the infection caused by this parasite. Due to the lack of studies on $H$. canis infection and its deleterious effects on the health of infected animals in the semi-arid region, we aimed to determine the prevalence of $H$. canis infection in dogs in the rural area of Sousa, Paraíba, and to describe the main epidemiological, clinical and hematological aspects of this infection.

\section{MATERIALS AND METHODS}

This study was conducted in the rural area of the municipality of Sousa, Paraíba (Lat. $06^{\circ} 45^{\prime} 33^{\prime \prime}$ $\mathrm{S}$; Long. $38^{\circ} 13^{\prime} 41^{\prime \prime} \mathrm{W}$ ), comprised of the districts of São Gonçalo, Núcleo I, Núcleo II, Núcleo III, Massapê dos Dias, and Emiliano Zapata Settlement (Figure 1). This municipality has a territorial area of $738,547 \mathrm{~km}^{2}$ and 7,369,161 habitants (IBGE, 2018). The region has a semi-arid climate, with an annual mean temperature of $26.6^{\circ} \mathrm{C}$ (INMET, 2010).

From April to December 2017, 98 blood samples were collected from dogs that were at
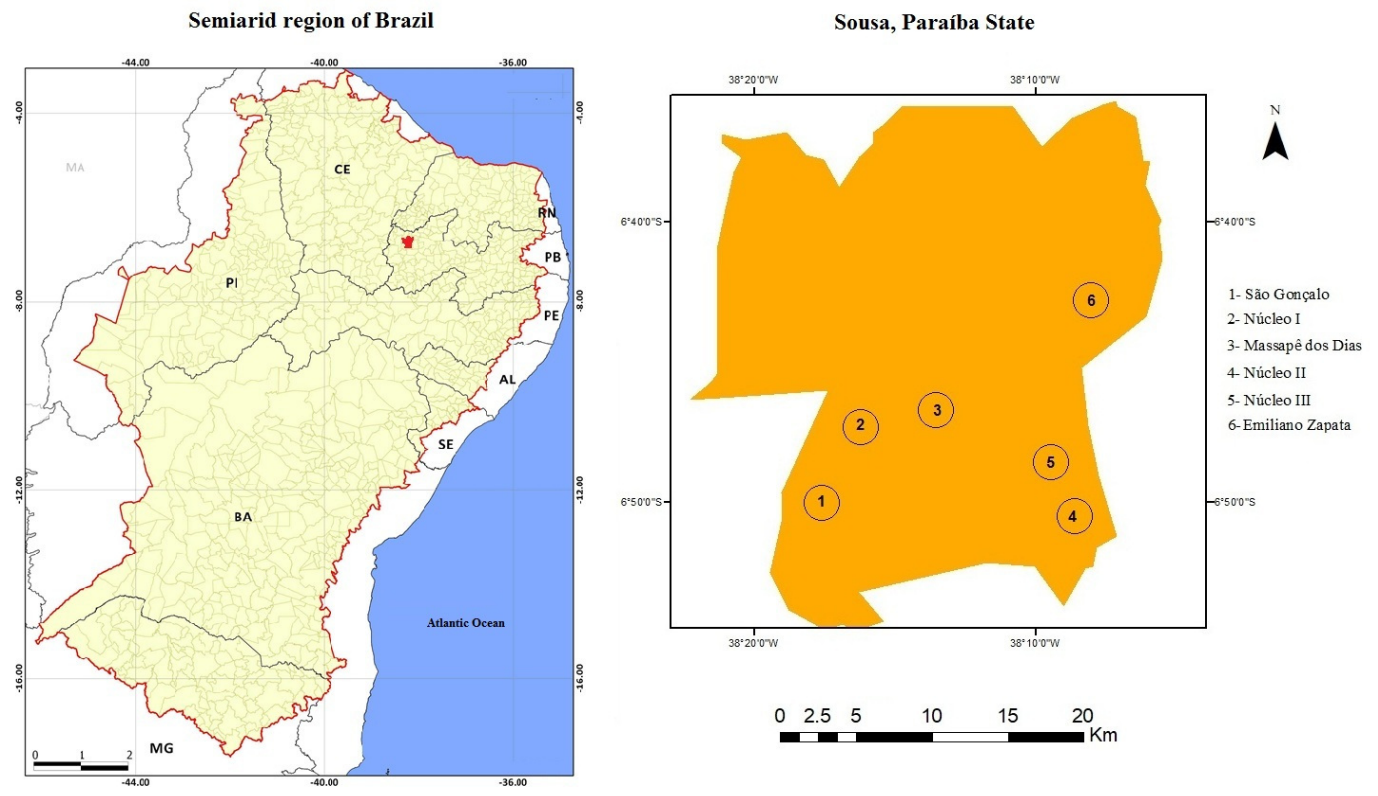

Figure 1 - Map of the rural areas of the municipality of Sousa, Paraíba, selected for examination of Hepatozoon canis infection. 
least four months old, regardless of their breed and gender, from the rural area of Sousa, Paraíba. The number of samples to be collected was calculated based on an expected prevalence of $9.3 \% \mathrm{H}$. canis infection, (BERNARDINO et al., 2016), confidence level of $95 \%$ and error of $5 \%$ (THRUSFIELD, 2005), resulting in 45 samples to be collected; however, 98 samples were collected for security.

Blood samples $(3.0 \mathrm{~mL})$ were collected from the external jugular vein of each animal, placed into tubes containing $10 \%$ EDTA, stored in styrofoam with ice, and submitted to the Laboratorio de Parasitologia Veterinária - LPV and to the Laboratório de Patologia Clínica - LPC, at the Hospital Veterinário Adílio Santos Azevedo - HV/ ASA, IFPB, Sousa, Paraíba. Blood counts were performed according to JAIN (1993). Blood smears were also performed at the collection site, using peripheral blood obtained with a lancet on the inner side of the ear tip, after trichotomy and asepsis with $70 \%$ alcohol.

Blood smears were made in order to categorically perform the differential leukometry and morphological evaluation of blood cells, as well as the search for blood parasites. The blood smears were stained with the Panótico Rápido ${ }^{\circledR}$ commercial kit, from Laborclin-products for laboratories LLC, Pinhais-PR (JAIN, 1993).

Hemoparasites were investigated by optical microscopy (100x objective) in blood extensions of systemic and peripheral blood (tip of ear), stained with the Panótico Rápido ${ }^{\circledR}$ kit (Laborclin-products for laboratories LLC, Pinhais-PR). In each slide, a total of 200 leukocytes were counted to obtain a reading pattern, and in order to determine the degree of parasitemia, the percentage of leukocyte infection (PLI) was determined by quantifying the leucocytes with gamont infection.

Considering other endemic diseases in the studied region, animals positive for $H$. canis were screened for Leishmaniasis (Leishmaniose Ac Test Kit ${ }^{\circledR}$ ), Heartworm (Dirofilariose Ag Test $\mathrm{Kit}^{\circledR}$ ), Ehrlichiosis (Erliquiose Ac Test Kit ${ }^{\circledR}$ ), Distemper (Cinomose Ag Test $\mathrm{Kit}^{\circledR}$ ), Parvovirus, and Coronavirus (Parvo-Corona Ag Test $\mathrm{Kit}^{\circledR}$ ) and Brucellosis (Brucelose Ac Test Kit $\left.{ }^{\circledR}\right)$. All the test kits were purchased from Alere TM - Veterinary Diagnosis, Belo Horizonte - MG.

To determine the clinical profile of the infected animals, we collected information about the history and physical examination of each animal using a form. Simultaneously, investigative questionnaires were applied to all animal guardians, containing objective and subjective questions about sanitary management, feeding, and contact with other animal species.
During the clinical examination, ectoparasites were collected and placed in flasks containing $70 \%$ ethanol, individualized by animal. The identification of ectoparasites was performed under a stereoscopic microscope according to traditional taxonomic keys (ARAGÃO \& FONSECA, 1961).

\section{Statistical analysis}

The data obtained from the epidemiological questionnaires were analyzed in two stages to determine the risk factors: univariate and multivariate analyses. Initially, the univariate analysis was performed with two groups of animals: positive and negative, and compared the analyzed variables between the two groups. The variables that presented a $p$-value $\leq 0.2$ by the chi-square test or Fisher's exact test (ZAR, 1999) were selected for multivariate analysis using the multiple logistic regression (HOSMER \& LEMESHOW, 2000). The level of significance adopted in the multivariate analysis was $5 \%$, and all analyses were performed with the SPSS 20.0 software for Windows.

\section{RESULTS}

A prevalence of $8.1 \%(8 / 98)$ of $H$. canis infection in dogs was obtained, based on the diagnosis through the visualization of gamonts under optical microscopy. Itwasobserved that $6.1 \%(6 / 98)$ werepositive for Ehrlichia spp., with no comorbidity with $H$. canis.

No other hemoparasites were diagnosed in the blood smears. All $H$. canis positive animals were negative for anti-Leishmania infantum, antiEhrlichia canis, and anti-Brucella canis antibodies and for Canine Distemper Virus, Canine Parvovirus, Canine Coronavirus, and Dirofilaria immitis.

According to the geographical distribution of the infected animals, there was a higher prevalence in the Emiliano Zapata Settlement 19.4\% (7/36), followed by São Gonçalo 5.2\% (1/11). In the other evaluated locations, there were no positive animals.

Among the 98 dogs evaluated, 57.1\% $(56 / 98)$ were males and $44.8 \%$ (44/98) were females; $7.1 \%$ (4/56) males and $9.09 \%$ (4/44) females were positive for $H$. canis infection. Regarding age, the distribution was: $<1$ year, 19 animals, $2(10.5 \%)$ of which were positive; $>1$ to $<3$ years, 30 animals, 1 (3.3\%) positive; and $>3$ years, 49 animals, 5 (10.2\%) positives. Furthermore, $87.5 \%(7 / 8)$ of the positive animals were mixed breed (SRD), and only one animal, of the Shitzu breed, was positive (12.5\%), with no statistically significant difference for these variables $(\mathrm{P}>0.05)$. 
The univariate analysis for the assessment of factors predisposing to $H$. canis infection is described in table 1. Regarding the most relevant predisposing factors, among the positive animals, $87.5 \%$ (7/8) were raised free, and 75\% (6/8) had infestations with $R$. sanguineus at the time of the clinical examination. Most of these $H$. canis infected animals had never received any vaccination $(87.5 \% ; 7 / 8)$. The variables presented in table 1 were selected $(\mathrm{P} \leq 0.20)$ for the multivariate analysis, however, no risk factors were identified by multiple logistic regression.

Systemic blood PLI ranged from 1 to $22 \%$, and that of peripheral blood from zero to $20 \%$. Among the infected dogs, seven (87.5\%) had anemia, six $(75 \%)$ had thrombocytopenia, and five (62.5\%) had hyperproteinemia, with a pattern of changes being observed mainly when the PLI was $\geq 5 \%$ (Table 2 ). Among the eight infected animals, three (37.5\%) showed all the clinical signs described in table 3 . The presence of at least two clinical signs was reported in $75 \%(6 / 8)$ of the animals, with the main associated signs being dry fur, pale mucous membranes, and lean or cachectic body score.

\section{DISCUSSION}

The prevalence of $H$. canis infection reported in the present study was $8.1 \%$, which is similar to the prevalence of $9.3 \%$ reported by BERNARDINO et al. (2016) in the municipality of Areia, Brejo Paraibano, but was higher than that reported by RAMOS et al. (2010), $0.49 \%$ in dogs in the metropolitan area of Recife-PE. ROTONDANO etal.(2010) didnotfound $H$. canis in dogs in urban areas in the municipality of Patos, in the semi-arid region of Paraíba. Probably, there was a greater ease of transmission of the parasite among the contact of dogs and the rural environment, due to the free access to other farms, a fact suggested by the high prevalence in one location: the Emiliano Zapata Settlement $(19,4 \% ; 7 / 36)$. Rhipicephalus sanguineus was the only species reported to infest positive animals, reinforcing the assertion that canine Hepatozoonosis is frequent in areas where this tick is endemic (SPOLIDORIO et al., 2009).

When comparing the positivity for $H$. canis in relation to the gender, breed and age of the animals, no statistically significant difference was observed ( $>0.05$ ). Probably, this is because the transmission of Hepatozoonosis depends on the ingestion of infected ticks, and the greatest epidemiological importance is in the presence of tick infestation, in which there is also no predisposition for the variables mentioned (LABRUNA \& PEREIRA, 2001).

Contrary to what is reported in the literature, that hepatozoonosis is a disease that develops with hematological changes without a pattern of association to the clinical signs (EIRAS et al., 2007; BERNARDINO et al., 2016), in the present study, there were simultaneously high levels of PLI in some animals with hematological changes and clinical symptomatology.

There were three main changes in the hematological status: thrombocytopenia, anemia, and hyperproteinemia, mainly related to PLI $\geq 5 \%$, and also to the presence of clinical signs, such as secretions, lymphadenomegaly, dry skin, pale mucous membranes, and lean or cachectic body score.

The most common hematological abnormalities in $H$. canis-infected dogs have been anemia, leukocytosis, and neutrophilia or lymphopenia (MUNDIM et al., 2008). Although,

Table 1 - Univariate analysis for the association between Hepatozoon canis infection and the management of dog breeding in the rural area of Sousa, semi-arid region of Paraíba State, Brazil.

\begin{tabular}{|c|c|c|c|c|c|}
\hline Variable & Cathegory & Total Number & Positive numbers (\%) & $P$ & Cramer's V values \\
\hline \multirow[t]{2}{*}{ Contact with Swine } & No & 79 & $2(2.5)$ & \multirow{3}{*}{0.001} & \\
\hline & Yes & 19 & $6(31.6)$ & & 0.419 \\
\hline \multirow[t]{2}{*}{ Contact with Sheep } & No & 79 & $5(6.3)$ & & \\
\hline & Yes & 19 & $3(15.8)$ & 0.182 & 0.137 \\
\hline \multirow[t]{3}{*}{ Breeding type } & Home bred & 6 & $0(0)$ & & \\
\hline & Home bred / Free & 39 & $1(2.5)$ & \multirow{2}{*}{0.138} & \\
\hline & Free & 53 & $7(13.2)$ & & 0.201 \\
\hline \multirow[t]{2}{*}{ Presence of Ticks } & No & 57 & $2(3,5)$ & \multirow{2}{*}{0.023} & \\
\hline & Yes & 41 & $6(14,6)$ & & 0.244 \\
\hline \multirow[t]{2}{*}{ Vaccination } & No & 52 & $7(13.5)$ & \multirow{2}{*}{0.063} & \\
\hline & Yes & 46 & $1(2.2)$ & & 0.206 \\
\hline
\end{tabular}


Hematological, clinical and epidemiological aspects of Hepatozoon canis infection by parasitological detection in dogs from the rural... 5

Table 2 - Percantage of leukocyte infection (PLI) and hematological parameters of dogs from rural areas positive for Hepatozoon canis in the Semiarid region of Paraíba State, Brazil.

\begin{tabular}{|c|c|c|c|c|c|c|c|c|c|c|}
\hline Animal $N^{\circ}$ & $\begin{array}{l}\text { PLI Sistemic } \\
\text { Blood }(\%)\end{array}$ & $\begin{array}{c}\text { PLI } \\
\text { Peripheral } \\
\text { Blood (\%) }\end{array}$ & $\begin{array}{c}\text { Total } \\
\text { Leukocytes } \\
(\mu / \mathrm{ml})\end{array}$ & $\begin{array}{l}\text { Platelets } \\
\qquad\left(10^{3}\right. \\
\left.\mathrm{mm}^{3}\right)\end{array}$ & $\begin{array}{l}\text { GV } \\
(\%)\end{array}$ & $\begin{array}{c}\mathrm{MCH} \\
\mathrm{C} \\
(\mathrm{g} / \mathrm{dl})\end{array}$ & $\begin{array}{l}\text { TPP } \\
(\mathrm{g} / \mathrm{dl})\end{array}$ & $\begin{array}{l}\mathrm{Hb} \\
(\mathrm{g} / \mathrm{dl})\end{array}$ & $\begin{array}{c}\text { Red Blood } \\
\text { Cell } \\
\left(10^{6} / \mu \mathrm{L}\right)\end{array}$ & $\begin{array}{l}\mathrm{ACV} \\
\text { (fl) }\end{array}$ \\
\hline 1 & 1 & 0 & 17,000 & 374 & 33 & 42 & 7,0 & 15 & 6,5 & 71,5 \\
\hline 2 & 8 & 15 & 20,100 & 100 & 24 & 59,08 & 9,5 & 14,18 & 4,8 & 50 \\
\hline 3 & 12 & 15 & 9,850 & 144 & 31 & 55,3 & 7,8 & 17,14 & 5,75 & 53,9 \\
\hline 4 & 22 & 20 & 15,650 & 44 & 21 & 64,8 & 9,8 & 13,62 & 3,6 & 58,3 \\
\hline 5 & 11 & 16 & 11,450 & 174 & 12 & 40,3 & 6,4 & 4,84 & 0,25 & 480 \\
\hline 6 & 5 & 5 & 16,100 & 90 & 20 & 64,5 & 8,9 & 18,97 & 3,1 & 64,5 \\
\hline 7 & 2 & 5 & 12,500 & 520 & 35 & 36,6 & 9,9 & 9,16 & 4,6 & 54,3 \\
\hline 8 & 1.5 & 2.5 & 14,200 & 183 & 41 & 32 & 8,9 & 13 & 5,8 & 74,3 \\
\hline $\begin{array}{l}\text { Reference } \\
\text { values }\end{array}$ & - & - & $\begin{array}{l}6,000- \\
17,000\end{array}$ & $200-500$ & $\begin{array}{l}37- \\
55\end{array}$ & $31-36$ & $5,5-8$ & $12-18$ & $5,5-8,5$ & $65-78$ \\
\hline
\end{tabular}

GV - Globular volume; MCHC - Mean corpuscular hemoglobin concentration; TPP - Total plasmatic proteins; Hb - Haemoglobin; ACV - Average corpuscular volume.

*Jain (1993).

albumin and globulin were not measured in the samples of the present study, it is believed that hyperproteinemia occurred due to hyperglobulinemia, as a result of the stimulation of the humoral response induced by $H$. canis (VINCENT-JOHNSON et al., 1997; O'DWYER et al., 2006; PAIZ et al., 2016). None of the dogs positive for $H$. canis presented leukocytosis. O'DWYER et al. (2006) also did not find any correlation between $H$. canis infection and leukocytosis. When analyzing 13 naturally infected dogs, they observed that only one animal had this alteration. However, according to GAUNT (2000), infection by $H$. canis can induced severe leukocytosis, with up to 200,000 leukocytes $/ \mu \mathrm{L}$, with a deviation to the left and an absence of toxic neutrophils.

Clinical hepatozoonosis was observed in 6 animals $(80 \%)$, related to PLI $>5 \%$, presenting ocular and nasal mucopurulent secretion, lymphadenomegaly, dry fur, pale mucous membranes, and/or lean or cachectic body score, considered to be nonspecific. In two animals (20\%), when the PLI was $<5 \%$, the infection occurred subclinically. In addition, no coinfections were found in animals positive for $H$. canis. The degree of parasitemia was also associated with the clinical manifestation as reported by KARAGENC et al., (2006), who stated that dogs with parasitemia up to $3 \%$ developed mild disease, up to $18 \%$ moderate disease, and up to $39 \%$ severe disease. However, it differs from the literature that characterizes the disease as intercurrent with other immunosuppressive diseases (BANETH et al., 2003; SPOLIDORIO et al., 2009; MEGID et al., 2016; AGUIAR et al., 2019).

Direct blood smear research has been described as highly specific, but with low

Table 3 - Main clinical signs observed in dogs positive for Hepatozoon canis in the rural area of Sousa, Paraíba State, Brazil.

\begin{tabular}{|c|c|c|c|c|c|}
\hline $\begin{array}{l}\text { Animal } \\
\text { Number }\end{array}$ & $\begin{array}{l}\text { Eye and nasal } \\
\text { discharge }\end{array}$ & Lymphadenomegaly & Dry hair & Pale mucous & Lean or cachectic \\
\hline 1 & - & - & - & - & - \\
\hline 2 & - & + & + & + & - \\
\hline 3 & + & - & - & + & + \\
\hline 4 & + & + & + & + & + \\
\hline 5 & + & + & + & + & + \\
\hline 6 & + & + & + & + & + \\
\hline 7 & - & - & + & + & - \\
\hline 8 & - & - & - & - & - \\
\hline
\end{tabular}

Ciência Rural, v.51, n.3, 2021. 
sensitivity (RAMOS et al., 2010; O'DWYER, 2011; ROTONDANO et al., 2015; PERLES et al., 2019). In general, when the parasitemia is high, blood smear is extremely efficient, however, at low levels of infection, detection becomes difficult. It is worth mentioning that low levels of parasitemia do not indicate absence of infection, and a false negative diagnosis is common in these cases (EIRAS et al., 2007). The diagnosis of $H$. canis can be done with serological and molecular tests for higher sensitivity, such as Indirect Fluorescence Antibody Test (IFAT), ELISA and Polymerase Chain Reaction (KARAGENC et al., 2006; O'DWYER et al., 2011).

During the present study, it was noted that the technique was effective not only for diagnosing the infection, but also for determining the percentages of the infection. It was noted that the observation of 200 leukocytes per slide in two slides, one of peripheral blood and the other of systemic blood, influenced the greater effectiveness of the technique.

In six $(75 \%)$ of the positive animals, a higher PLI was observed in peripheral blood smears than in systemic blood. This occurs, according to VINCENT-JOHNSON et al. (1997), because the gametocytes quickly leave the leukocytes after blood sampling, mainly through contact between the blood and the anticoagulant, which may make it difficult to search for gametocytes in blood smears.

Most positive animals belonged to families that lived in precarious socio-economic conditions, lacking knowledge about the correct handling of animals, where basic health and food care was neglected. Moreover, as they come from rural areas, many animals were confined during the day and released at night to protect the homes. These factors, linked to the environmental conditions that favored the tick cycle, made the animals more predisposed to the infection, favoring the high prevalence observed and the occurrence of animals with a chronic infection status.

For the control of $H$. canis infections, infestation of animals by ticks should be avoided. Considering the high prevalence found, it is advisable that veterinarians carry out the search for hemoparasites, with slides of peripheral and systemic blood, observing at least 200 leukocytes per slide, especially when there are cases of hematological changes and non-specific clinical signs. This study demonstrated the need for continuous epidemiological studies, for the detection of endemic areas for hepatozoonosis, since it is a disease with a difficult clinical diagnosis.

It was concluded that the prevalence of $H$. canis infection in dogs in the rural area of Sousa,
Paraíba, was high, with the majority of positive animals showing simultaneously hematological changes, clinical symptomatology and a high degree of parasitemia.

\section{ACKNOWLEDGEMENTS}

The authors would like to thank Instituto Federal de Educação, Ciência e Tecnologia da Paraíba for the fellowship to L. O.

\section{BIOETHICS AND BIOSSECURITT COMMITTEE APPROVAL}

The study was approved by the Animal Care and Ethics Committee, Instituto Federal da Paraíba, Sousa, Paraíba, Brazil (Approval number: 23000,000773,2017-48).

\section{DECLARATION OF CONFLICT OF INTERESTS}

The authors declare no conflict of interest. The founding sponsors had no role in the design of the study; in the collection, analyses, or interpretation of data; in the writing of the manuscript, and in the decision to publish the results.

\section{AUTHORS' CONTRIBUTIONS}

LO, TF, AB and VV designed the experiments. LO, $\mathrm{RO}$, EA and FA performed the experiments. TF, AB, and VV analyzed the data. $\mathrm{LO}$ and $\mathrm{VV}$ wrote and edited the manuscript.

\section{REFERENCES}

AGUIAR, D. M. et al. Uncommon Ehrlichia canis infection associated with morulae neutrophils from naturally infected dogs in Brazil. Transboundary and Emerging Diseases. v.1, n.1, p.17, Nov. 2019. Available from: <https://onlinelibrary.wiley.com/doi/ full/10.1111/tbed.13390> Accessed: Oct. 19, 2020. doi: 10.1111/ tbed.13390.

ANDRÉ, M. R. et al. Molecular detection of Hepatozoon spp. in Brazilian and exotic wild carnivores. Veterinary Parasitology. v.173, n.1-2, p.134-138. 2010. Available from: <http://hdl. handle.net/11449/42015> Accessed: Oct 19, 2020. doi: 10.1016/j. vetpar.2010.06.014.

ARAGÃO, H.; FONSECA, F. Notas de Ixodologia. VIII. Lista e chave para os representantes da fauna ixodológica brasileira. Memórias do Instituto Oswaldo Cruz. v.59, n. 1, p.115-129. 1961. Available from: $<$ https://www.scielo.br/scielo.php?script=sci_artte xt\&pid=S0074-02761961000200001>. Accessed: Oct 19, 2020. doi: 10.1590/S0074-02761961000200001.

BANETH G. et al. Canine hepatozoonosis: two disease syndromes caused by separate Hepatozoon spp. Trends in Parasitology. v.19, n.1, p.27-31. 2003. Available from: $<$ https://doi.org/10.1016/ S1471-4922(02)00016-8>. Accessed: Oct 19, 2020. doi: 10.1016/ S1471-4922(02)00016-8.

BERNARDINO, M. G. S. et al. Prevalência de hepatozoonose canina no município de Areia, Paraíba, Brasil. Biotemas. v.29, n.1, 
p.175-179. 2016. Available from: <https://doi.org/10.5007/2175 7925.2016v29n1p175>. Accessed: Oct. 19, 2020. doi: 10.5007/2175-7925.2016v29n1p175.

EIRAS, D. F. et al. First molecular characterization of canine hepatozoonosis in Argentina: evaluation of asymptomatic Hepatozoon canis infection in dogs from Buenos Aires. Vetetrinary Parasitololoy. v.149, n.3-4, p.275-279. 2007. Available from: $<$ https://pubmed.ncbi.nlm.nih.gov/17720320/>. Accessed: Oct. 19, 2020. doi: 10.1016/j.vetpar.2007.07.010

GAUNT, S. D. et al. Veterinary hematology. Philadelphia: Lippincot Willians \& Wilkins. 2000. $5^{\circ}$ ed. Cap. 52. p.347.

GONÇALVES, L. R. et al. Study on coinfecting vector-borne pathogens in dogs and ticks in Rio Grande do Norte, Brazil. Brazilian Journal of Veterinary Parasitology. v.23, n.3, p.406-412. 2014. Available from: <https://www.scielo.br/scielo. php?pid $=$ S1984-29612014000300407\&script $=$ sci_abstract $>$. Accessed: Oct. 19, 2020. doi: 10.1590/S1984-29612014071.

HOSMER, D. W. \& LEMESHOW, S. Applied logistic regression New York: John Wiley \& Son, 2000. $2^{\circ}$ ed. p. 375.

INSTITUTO BRASILEIRO DE GEOGRAFIA E ESTATÍSITCA (IBGE). Resultados censo 2010. Available from: <https:// censo2010.ibge.. ov. br/noticias-censo.html?id $=1$ \&idnoticia $=2902$ \&view=noticia $>$. Accessed: Nov. 29, 2019.

JAIN, N. C. Essentials of veterinary hematology. Philadelphia: Lea \& Febinger, 1993.

KARAGENC, T. I. et al. A parasitological, molecular and serological survey of Hepatozoon canis infection in dogs around the Aegean coast of Turkey Veterinary Parasitology. v.135, n.2, p.113-119. 2006. Available from: <https://pubmed.ncbi.nlm. nih.gov/16229952/>. Accessed: Oct 19, 2020. doi: 10.1016/j. vetpar.2005.08.007.

LABRUNA, M. B.; PEREIRA, M. C. Carrapato em cães no Brasil. Clínica Veterinária, v.6, n.30, p.24-32. 2001. Available from $<$ http://r1.ufrrj.br/adivaldofonseca/wp-content/uploads/2014/06/ Labruna-et-al-2001-carrapatos-caes-CLIN-VET.pdf>. Accessed: Oct. $19,2020$.

LOPES, M. G. et al. Occurrence of Ehrlichia canis and Hepatozoon canis and probable exposure to Rickettsia amblyommatis in dogs and cats in Natal, RN. Brazilian Journal of Veterinary Parasitology. v.28, n.1, p.151-156. 2019. Available from: <https://www.scielo. br/pdf/rbpv/v28n1/1984-2961-rbpv-S1984-296120180065.pdf>. Accessed: Oct. 19, 2020. doi: 10.1590/s1984-296120180065.

MEGID, J. et al. Doenças infecciosas em animais de produção de companhia. 1. ed. Rio de Janeiro: Roca, 2016

MIRANDA, R. L. et al. Oocysts of Hepatozoon canis in Rhipicephalus (Boophilus) microplus collected from a naturally infected dog. Veterinary Parasitology. v.177, n.1, p.392-396. 2011. Available from: <https://pubmed.ncbi.nlm. nih.gov/21324597/> Accessed: Oct. 10, 2020. doi: 10.1016/j. vetpar.2011.01.044.

MUNDIM, A. V. et al. Clinical and hematological signs associated with dogs naturally infected by Hepatozoon sp. and with other hematozoa: A retrospective study in Uberlândia, Minas Gerais, Brazil. Veterinary Parasitology. v.153, n.1-2, p.3-8. 2008.
Available from: <https://pubmed.ncbi.nlm.nih.gov/18304739/>. Accessed: Oct. 19, 2020. doi: 10.1016/j.vetpar.2008.01.018.

O'DWYER, L. H. Brazilian canine hepatozoonosis. Revista Brasileira de Parasitologia Veterinária.v.20,n.3,p.181-193.2011. Available from: $<$ https://www.scielo.br/scielo.php?script=sci_artte xt\&pid=S1984-29612011000300002 > . Accessed: Oct. 19, 2020. doi: $10.1590 /$ S1984-29612011000300002.

O'DWYER, L. H. et al. Prevalence, hematology and serum biochemistry in stray dogs naturally infected by Hepatozoon canis in São Paulo. Arquivo Brasileiro de Medicina Veterinária e Zootecnia. v., n.4, p.688-690. 2006. Available from: $\quad<$ https://www.scielo.br/scielo.php?script=sci_arttext\&pi $\mathrm{d}=\mathrm{S} 0102-09352006000400039>$. Accessed: Oct. 19, 2020. doi: $10.1590 / \mathrm{S} 0102-09352006000400039$.

PAIZ, L. M. et al. Hematological disorders detected in dogs infected by Hepatozoon canis in a municipality in Mato Grosso do Sul State, Brazil. Arquivo Brasileiro de Medicina Veterinária e Zootecnia. v.68, n.5, p.1187-1194. 2016. Available from: $<$ https://www.scielo.br/scielo.php?pid=S0102$09352016000501187 \&$ script $=$ sci_abstract $>$. Accessed: oct 19 , 2020. doi: $10.1590 / 1678-4162-8350$.

PERLES, L. et al. Hepatozoon sp. Gamonts as na acidental finding in synovial liquid from injured maned Wolf (Chrusocyon brachyurus) in southeastern Brazil. Brazilian Journal of Veterinary Parasitology. v.28, n.4, p.779-785. 2019. Available from: $<$ https://www.scielo.br/scielo.php?pid=S1984$29612019000400779 \&$ script $=$ sci abstract $>$. Accessed : Oct. 19, 2020. doi: $10.1590 / \mathrm{s} 1984-29612019062$

RAMOS, C. A. N. et al. Molecular identification of Hepatozoon canis in dogs from Campo Grande, Mato Grosso do Sul, Brazil. Brazilian Journal of Veterinary Parasitology. v.24, n.2, p.247-250. 2015. Available from: <https://www.scielo.br/scielo. php?script $=$ sci_arttext\&pid $=$ S1984-29612015000200247 $>$. Accessed: Oct. 19 , 2020. doi: 10.1590/S1984-29612015019.

RAMOS, R. et al. Molecular survey and genetic characterization of tick-borne pathogens in dogs in metropolitan Recife (northeastern Brazil). Parasitology Research. v.107, p.1115-1120, 2010. Available from: <https://pubmed.ncbi.nlm.nih.gov/20680344/>. Accessed: Oct. 19, 2020. doi: 10.1007/s00436-010-1979-7.

ROTONDANO, T. E. F. et al. Survey of Ehrlichia canis, Babesia spp. and Hepatozoon spp. in dogs from a semiarid region of Brazil. Brazilian Journal of Veterinary Parasitology. v.24, n.1, p.52-58, 2015. Available from: <https:// www.scielo.br/scielo.php?script=sci_arttext\&pid $=\mathrm{S} 1984$ 29612015000100007\&lang=en>. Accessed: oct 19, 2020. doi: $10.1590 / \mathrm{S} 1984-29612015011$

SILVEIRA J. A. et al. Rangelia vitalii in a free-ranging maned wolf (Chrysocyon brachyurus) and co-infections. International Journal for Parasitology: Parasites and Wildlife. v. 5, n. 3, p.280-285. 2016. Available from: <https://www.sciencedirect. com/science/article/pii/S2213224416300335> Accessed in: oct 19 , 2020. doi: 10.1016/j.ijppaw.2016.09.003.

SPOLIDORIO, M. G. et al. Hepatozoon canis infecting dogs in the State of Espírito Santo, Southeastern Brazil. Veterinary Parasitology. v.163, n.4, p.357-361, 2009. Available from: $<$ https://pubmed.ncbi.nlm.nih.gov/19482427/>. Accessed: Oct 19, 2020. doi: 10.1016/j.vetpar.2009.05.002 
1 THRUSFIELD, M. Veterinary Epidemiology. Cambridge: Blackwell Science. 2005. 2v, 479p.

4 VINCENT-JOHNSON, N. A. et al. A New Hepatozoon Species 5 from Dogs: Description of the Causative Agent of Canine 6 Hepatozoonosis in North America. The Journal of Parasitology. v.83, n.6, p.1165. 1997. Available from: <https://www.jstor. org/stable/3284379?seq=1>. Accessed: Oct. 19, 2020. doi: $10.2307 / 3284379$.

ZAR, J. H. Biostatistical Analysis. New Jersey: Prentice-Hall. $4^{\circ}$ ed. 1999. 